\title{
Simultaneous determination for fungicide prochloraz and its metabolites in animal commodities with GC-ECD after hydrolysis
}

\author{
Ji-Su Park ${ }^{1,2}$ (D) $\cdot$ Hoon Choi ${ }^{1}$ (I) \\ 가수분해 후 GC-ECD를 이용한 축산물 중 살균제 Prochloraz 및
그의 대사물의 동시분석
}

박지수 ${ }^{1,2} \cdot$ 최 훈 ${ }^{1}$

Received: 19 May 2020 / Accepted: 5 June 2020 / Published Online: 30 June 2020

(C) The Korean Society for Applied Biological Chemistry 2020

\begin{abstract}
The analytical method was established for simultaneous determination of fungicide prochloraz and its metabolites in several animal commodities using gas chromatography (GC) coupled with electron capture detector (ECD). Samples including beef meat, pork meat, chicken meat, milk, and egg were hydrolyzed with pyridine hydrochloride which converts prochloraz and its metabolites to 2,4,6-trichlorophenol (2,4,6-TCP) because residue definition for prochloraz was 'sum of prochloraz and its metabolites containing the 2,4,6-trichlorophenol moiety, expressed as prochloraz', for compliance with MRLs from animal commodities. Therefore, residual prochloraz was extracted with acetone, decomposed to 2,4,6-TCP, partitioned with dichloromethane, purified with aminopropyl SPE and quantified as 2,4,6-TCP with GC-ECD. The instrumental limit of quantitation and method LOQ (MLOQ) was $0.01 \mu \mathrm{g} / \mathrm{mL}$ and $0.02 \mathrm{mg} / \mathrm{kg}$ for prochloraz and $0.005 \mu \mathrm{g} / \mathrm{mL}$ and $0.01 \mathrm{mg} / \mathrm{kg}$ for $2,4,6-\mathrm{TCP}$, respectively. The linearity of the calibration curve was good with $\mathrm{R}^{2}>0.995$ in the range of 0.005 -

Hoon Choi $(\bowtie)$

E-mail: hchoi0314@wku.ac.kr

${ }^{1}$ Department of Bio-Environmental Chemistry, College of Agriculture and Food Sciences, Wonkwang University, Iksan 54538, Republic of Korea

${ }^{2}$ Pesticide and Veterinary Drug Residues Division, Food Safety Evaluation Department, National Institute of Food and Drug Safety Evaluation, Ministry of Food and Drug Safety, Cheongju 28159, Republic of Korea

This is an Open Access article distributed under the terms of the Creative Commons Attribution Non-Commercial License (http://creativecommons. org/licenses/by-nc/3.0/) which permits unrestricted non-commercial use, distribution, and reproduction in any medium, provided the original work is properly cited.
\end{abstract}

$0.2 \mu \mathrm{g} / \mathrm{mL}$. Fortification levels of prochloraz were $0.02 \mathrm{mg} / \mathrm{kg}$ (MLOQ) and $0.2 \mathrm{mg} / \mathrm{kg}$ (10MLOQ) for recovery tests. Overall recoveries of prochloraz were $>90 \%$ with $<10 \%$ of coefficient variation (C.V.). This established analytical method was fully validated and could be useful for quantification of prochloraz and its metabolites in animal commodities as official analytical method.

Keywords Analytical method Animal commodities $\cdot$ Prochloraz 2,4,6-trichlorophenol

\section{서 론}

우리나라 국민들의 생활수준이 향상되고 축산업의 발전에 힘입 어 축산 식품의 소비는 과거에 비해 크게 증가하였으며, 농림 축산식품 주요통계에 의하면 16 년 기준 1 인당 소비량은 돼지고 기 $24.1 \mathrm{~kg}$, 닭고기 $13.8 \mathrm{~kg}$, 소고기 $11.6 \mathrm{~kg}$, 우유 $76.4 \mathrm{~kg}$, 계 란 274개로 조사되었고 과거 5년동안 1 인 소비량은 고기류(돼 지고기, 소고기, 닭고기) $22.2 \%$, 우유 $13.7 \%$, 계란 $13.2 \%$ 증가 하였다[1]. 축산물의 수요가 증가하면서 국외에서 수입되는 물 량 또한 증가하였는데, 16 년 기준으로 과거 5년간 국내의 축산 물 생산량은 연간 소비되는 고기류(돼지고기, 쇠고기, 닭고기)의 $68.1 \%$, 우유 $54.4 \%$ 만을 차지하였고 수입 물량은 5년간 고기류 $22 \%$, 우유 $29.6 \%$ 증가하였다[1]. 따라서, 국민건강과 직결되는 축산물의 안전성은 국내 생산되어 유통되는 축산물 뿐 아니라 수입 축산물에서도 함께 보증될 필요가 있다. 축산물의 안전성 을 저해하는 요인으로는 크게 미생물과 잔류유해물질로 구분되 며 잔류유해물질인 동물용의약품이나 사료를 통해 축산물에 유 
<smiles>CCCN(CCOc1c(Cl)cc(Cl)cc1Cl)C(=O)n1ccnc1</smiles>

2,4,6-trichlorophenol

Fig. 1 Decomposition of prochloraz and its metabolites into 2,4,6-trichlorophenol

입가능한 잔류농약은 먹이사슬을 통해 동물이나 사람의 체내에 축적되어 생식기능 저하, 기형, 급성 및 만성 독성 유발 및 호 르몬계에 악영향을 미치는 것으로 알려져 있다. 가축사육기간 동안 질병 예방 및 치료를 목적으로 사용하는 동물용의약품은 사용허가에 따른 주기적 잔류실태조사를 통해 동물용의약품 사 용 및 잔류에 따른 안전성을 관리하고 있으나, 가축사료는 국 외의존도가 높아 주로 국외에서 재배생산된 사료작물로 사료조 제가 이루어지며 사료작물 생산 시 사용등록된 농약성분은 제 외국마다 상이하기 때문에 국내로 수입되는 축산물 중 사료를 통해 축산물에 유입된 잔류농약의 안전관리는 상대적으로 미흡 한 실정이다. 따라서, 사료작물에 사용되는 농약성분 중 prochloraz의 잔류분석법을 개발하여 축산물 중 잔류농약 안전 관리에 활용코자 하였다.

Prochloraz는 과수류, 채소류 등에서 발생하는 탄저병, 잿빛곰 팡이병, 흰가루병을 예방하기 위하여 사용되는 imidazole계 살 균제로서, 벼에서는 종자소독용으로 사용되어지고 있다[2]. 침투 이행성으로 식물체내로 침투하여 균사체까지 박멸하는 특성을 가져 오랜기간 작물체내 잔류할 가능성이 높고, 세포막의 구성 성분인 ergosterol의 생합성을 저해하는 작용을 이용하여 보호 및 치료의 목적으로 사용되고 있다. Prochloraz는 rat에 대해 경 구 $\mathrm{LD}_{50} 1023 \mathrm{mg} / \mathrm{kg}$ bw, 피부 $\mathrm{LD}_{50}>2100 \mathrm{mg} / \mathrm{kg}$ bw 및 흡 입 $>2.16 \mathrm{mg} / \mathrm{L}(4 \mathrm{~h})$ 으로 급성독성이 낮으며, 1 일섭취허용량 (ADI, Acceptable Daily Intake)이 $0.01 \mathrm{mg} / \mathrm{kg}$ bw/day로 인축 독성이 낮은 농약이다[3]. Prochloraz를 밀, 옥수수 등 사료용 농작물 재배기간 중에 사용할 경우 사료로 사용되는 부위 또는 가공 중 발생하는 부산물로 제조된 사료를 통해 잔류물이 축산
물로 이행될 수 있다. 산유염소 및 산란계에 prochloraz를 투여 하였을 때 prochloraz는 빠르게 대사되어 대소변으로 배설되며, 대사물 BTS 44595 ( $N$-propyl- $N^{\prime}-2$-(2,4,6-trichlorophenoxy)ethylurea), BTS 44596 ( $N$-formyll- $N$-propyl- $N$-[2-(2,4,6-trichlorophenoxy)ethyl]urea), BTS 44770 ( $N$-2-(2,4,6-trichlorophenoxy)ethylurea), BTS 54906 (2-(2,4,6-trichloro-3-hydroxyphenoxy)ethanol) 등이 간, 신장 등 주요 조직내 주요 잔류물로써 잔류하였다[4].

앞선 일반적인 prochloraz 잔류분석법은 prochloraz를 2,4,6trichlorophenol(2,4,6-TCP)로 분해 후 gas chromatrography (GC)ECD (electron capture detector) 또는 GC-mass spectrometry (MS)로 분석하는 방법이 제시되어 있으나[5-7], 현행 식품공전 내 축산물 중 잔류분석법은 6시간 이상의 soxhlet 추출을 해야 하고 정제과정이 복잡하여 전처리 시간이 오래 소요되는 등 정 량성이 열등하고 분석법의 신뢰성이 낮은 제한점을 가지고 있 다[8]. 일부 liquid chromatography (LC)-MS를 이용하여 prochloraz 및 대사산물를 동시에 개별분석한 경우가 있으나[9], 농산물 및 축산물 중 prochloraz의 잔류분은 'prochloraz와 2,4,6-trichlorophenol 기를 포함하고 있는 대사산물의 합을 prochloraz로 함'으로 정 의되어 있기 때문에 보다 정확한 잔류분 정량분석을 위해서는 일부 특정 대사산물을 분석성분으로 한정하기 보다는 많은 종 류의 대사체를 일괄분석하는 분석법이 필요하며 정량물질인 2,4,6-TCP은 분자구조내에 할로겐 원소인 chloride를 3 개 함유 하고 있어 검출기로써 선택성과 분석감도가 우수한 $\mathrm{ECD}$ 를 활 용하는 것이 범용적으로 활용할 수 있는 방법이다. 따라서, 본 연구에서는 prochloraz 및 2가지 대사물이 공통적으로 2,4,6trichlorophenol moiety를 가지고 있으므로 모든 분석대상 화합 
물을 2,4,6-TCP로 분해 및 정량한 후 prochloraz로써 환산정량 하도록 하였으며(Fig. 1), 추출, 분배, 분해, 정제 등 전처리 과 정별 최적화를 시도하여 정량성과 정밀성이 확보된 잔류분석법 을 확립하고자 하였다.

\section{재료 및 방법}

\section{시약 및 초자}

본 연구에 사용된 표준품 prochloraz (98.6\%), BTS44595 (1-propyl1-[2-(2,4,6-trichloro-phenoxy)ethyl]urea) (99.2\%), BTS44596 (3-formyl-1-propyl-1-[2-(2,4,6-trichlorophenoxy)ethyl]urea) (99.3\%) 은 Sigma-Aldrich (St. Louis, MO, USA)사로부터 구입하였으 며, 2,4,6-TCP (2,4,6-trichlorophenol) (99.0\%)는 Chem Service (West Chester, PA, USA)사에서 구입하여 사용하였다. 분해용 vial로는 Verex vial $40 \mathrm{~mL}$ 를 Phenomenex (Torrance, CA, USA) 사로부터 구입하여 사용하였고, $\mathrm{NH}_{2} \mathrm{SPE}$ cartridge $(1 \mathrm{~g}, 6 \mathrm{cc})$ 는 Waters Co. (Milford, MA, USA)사로부터 구입하였다. 사용 된 용매로 acetonitrile (J.T. Baker ${ }^{\circledR}$, Avantor, Radnor, PA, USA), acetone, dichloromethane, $n$-hexane 및 methanol (Daejung Chemicals \& Metals, Siheung, Korea, 이상)은 HPLC급을 사 용하였다. Sodium chloride와 sodium sulfate, anhydrous는 GR 급으로 Junsei Chemical Co. (Tokyo, Japan)에서 구입하였고, pyridine hydrochloride $(98 \%)$ 는 Sigma-Aldrich사로 구입하여 사용하였다. 고기류 균질화는 MG516 Meat grinder Pro 1600 (Kenwood, Havant, UK), 시료 추출을 위한 homogenizer는 AM-7 (Nihonseiki kaisha Ltd., Tokyo, Japan), 추출액 여과에는 GF/A 여과지(Whatman International Ltd., Maidstone, UK), 추 출액 농축은 R-114 (Buchi, Flawil, Switzerland), 원심분리기로 는 Combi-408 (Hanil Science Industrial Co., Ltd., Gwangju, Korea)를 사용하였다.

\section{축산물 시료}

대표 축산물 시료 선정을 위해 식품공전 및 $\mathrm{CODEX}$ 의 축산물 농약 잔류허용기준 적용범위 및 빈도, 1 인당 식품 소비량 등을 고려하여 검토한 결과 포유류에서는 소고기 등심과 돼지고기 삼 겹살, 가금류에서는 닭고기 다리살, 유 및 유가공품에서는 우유, 알류에서는 계란으로 결정하였다. 대표 축산물은 지역 마트에서 구매하였으며, 고기류는 고기 분쇄기를 이용하여 2번 이상 균 질화하였고 계란의 경우 껍질을 제거 후 균일하게 섞어준 뒤 거름망을 이용하여 걸러주었다. 균질화된 고기류는 $-20{ }^{\circ} \mathrm{C}$ 냉 동고에서 보관하였고 유 및 계란은 전처리할 때마다 구매하여 균질화 수 사용하였다.

\section{표준용액 조제}

표준품의 일정량을 acetonitrile에 녹여 $100 \mathrm{mg} / \mathrm{L}$ 의 stock solution 을 조제하였고, BTS44596의 경우 $0.4 \%$ formic acid를 함유한 acetonitrile에 녹여 조제하였다. Stock solution은 $4{ }^{\circ} \mathrm{C}$ 에서 냉장 보관하였고 필요시 마다 일정량을 취하여 ethyl acetate에 희석 하여 $0.005-0.2 \mu \mathrm{g} / \mathrm{mL}$ 의 working solution을 조제하여 사용하 였다.

\section{GC-ECD 기기분석}

Prochloraz 잔류분인 2,4,6-TCP 분석을 위해 Agilent Technologies (Santa Clara, CA, USA)의 $6890 \mathrm{GC}$ model에 ${ }^{63} \mathrm{Ni}-\mathrm{ECD}$ 를 부 착하여 사용하였다. 분석 column은 DB-5 capillary column (30 $\mathrm{m} \times 0.53 \mathrm{~mm}$ I.D., $0.50 \mu \mathrm{m}$, Agilent)를 사용하였으며, 이동상 기 체로는 $\mathrm{N}_{2}$ 를 사용하여 유속은 $7 \mathrm{~mL} / \mathrm{min}$ 였으며 make-up gas 유속은 $60 \mathrm{~mL} / \mathrm{min}$ 이었다. Oven 온도는 $110^{\circ} \mathrm{C}$, injector port 및 detector block 온도는 $300^{\circ} \mathrm{C}$ 이었으며, 기기주입량은 $1 \mu \mathrm{L}$ 으 로 splitless mode로 분석하였다.

\section{GC-ECD 분석법 검중}

2,4,6-trichlorophenol의 표준용액 $0.001-0.5 \mu \mathrm{g} / \mathrm{mL}$ 를 $1 \mu \mathrm{L}$ 씩 주 입하여 chromatogram상의 $\mathrm{s} / \mathrm{n}$ ratio(signal과 noise의 비)가 3 또는 10 이상인 농도를 기기검출한계(Instrumental Limit of Detection, ILOD)와 기기정량한계(Instrumental Limit of Quantitation, ILOQ)를 설정하였다. $2,4,6-\mathrm{TCP}$ 의 표준용액 $0.005 \mathrm{mg} / \mathrm{L}$ 를 7 번 반복 분석하여 재현성을 확인하였으며, $0.005-0.2 \mu \mathrm{g} / \mathrm{mL}$ 의 working solution을 분석하여 표준 검량선 작성 및 직선성을 확 인하였다.

\section{고기류 추출물 중 지질 제거효율 검토}

고기류의 지질을 제거하기 위해 $n$-hexane/acetonitrile 분배법을 검토하였다. Acetonitrile이 포화된 $n$-hexane $30 \mathrm{~mL}$ 에 prochloraz 및 각 대사물의 표준용액 $10 \mu \mathrm{g} / \mathrm{mL}, 1 \mathrm{~mL}$ 을 첨가한 후 $n$ hexane이 포화된 acetonitrile $30 \mathrm{~mL}$ 를 이용하여 2회 분배 추출 하였으며, $1 \%$ formic acid를 함유하고 $n$-hexane이 포화된 acetonitrile를 이용하는 방법도 검토하였다. 또한, 지질 제거 효 과를 검증하기 위해 고기류 중 지방함량이 가장 높은 돼지고기 $10 \mathrm{~g}$ 에 추출용매 acetone 또는 acetonitrile $100 \mathrm{~mL}$ 첨가하여 30 분 동안 $200 \mathrm{rpm}$ 에서 진탕 추출하고 농축한 후 추출 고형물의 무게를 측정 후 확립된 $n$-hexane/acetonitrile 분배법을 통해 제 거된 지질의 양을 측정하였다.

\section{우유 및 계란 추출물의 액-액 분배법 검토}

계란과 우유는 지질함량이 낮기 때문에 $n$-hexane/acetonitrile 분 배법이 아닌 dichloromethane를 이용한 액-액 분뱁법을 검토하 였다. 각 표준원액 $10 \mu \mathrm{g} / \mathrm{mL}, 1 \mathrm{~mL}$ 씩 첨가한 후 분배조건을 확 인하였다. 첫번째 분배 방법은 추출 후 포화식염수 $50 \mathrm{~mL}$ 와 과 량의 물을 넣은 후 dichloromethane $50 \mathrm{~mL}$ 로 두 번 분배하는 방법이었고 두번째 검토한 분배법은 추출액을 농축한 다음 포 화식염수 $50 \mathrm{~mL}$ 와 증류수 $200 \mathrm{~mL}$ 첨가 후 dichloromethane으 로 $50 \mathrm{~mL}$ 로 두 번 분배하는 방법이었다.

\section{Prochloraz 및 대사물의 2,4,6-TCP로 분해조건 설정}

최적의 열분해 온도를 확립하기 위해 prochloraz 표준용액 $1 \mu \mathrm{g} /$ $\mathrm{mL}, 1 \mathrm{~mL}$ 를 분해용 vial에 담은 후 질소 건조하고 pyridine hydrochloride $5 \mathrm{~g}$ 첨가한 다음 분해온도 200,210 또는 220 ${ }^{\circ} \mathrm{C}$ 에서 1 시간씩 가열한 후 상온에서 방치하고 $0.2 \mathrm{M} \mathrm{HCl}$ 수용 액 $20 \mathrm{~mL}$ 에 재용해한 다음 dichloromethane $50 \mathrm{~mL}$ 으로 2 번 분배하였다. 분배액 농축 중 $2,4,6-\mathrm{TCP}$ 의 휘발소실을 방지하기 위해 분배액에 $2 \%$ diethylene glycol $0.2 \mathrm{~mL}$ 를 첨가 후 감압농 

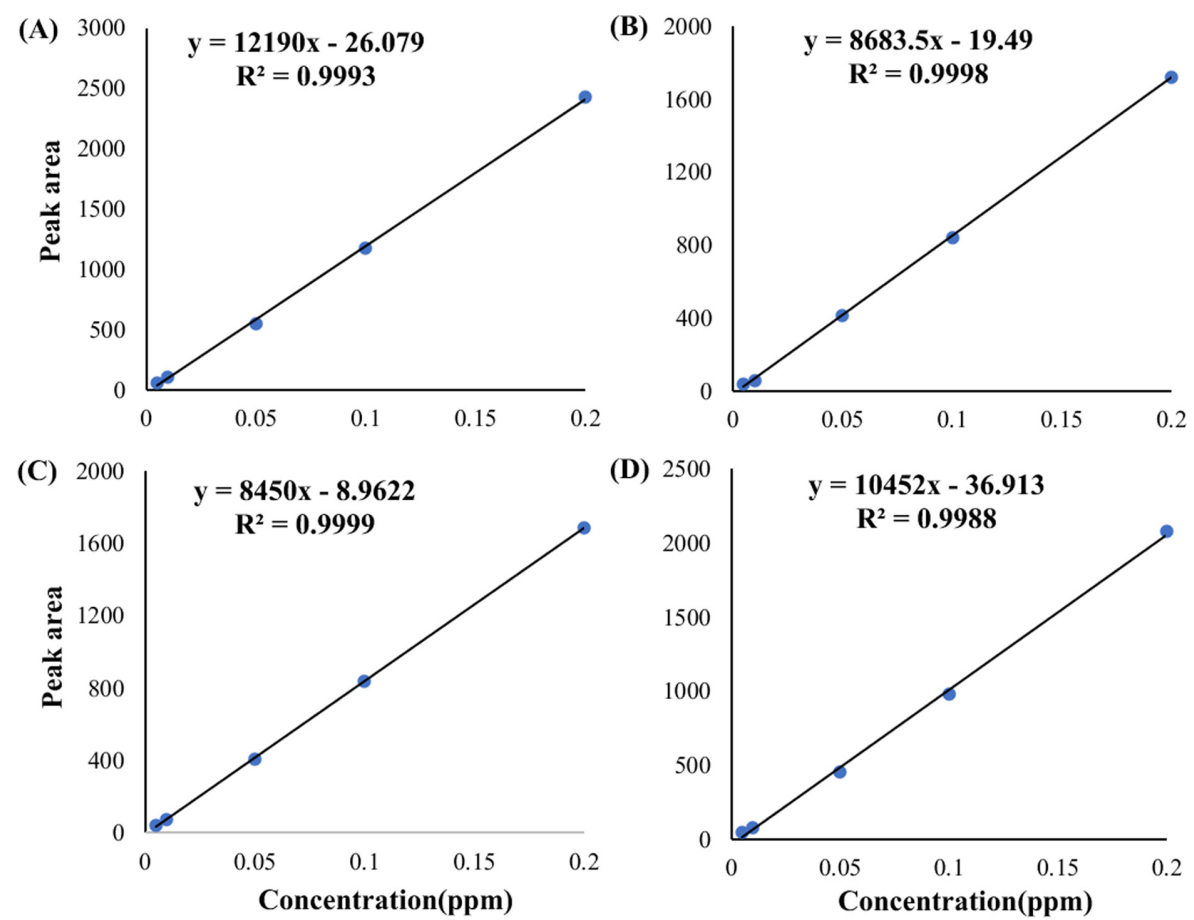

Fig. 2 Calibration curve of 2,4,6-trichlorophenol in animal commodities. (A) beef meat, (B) pork meat, (C) chicken meat, (D) milk \& egg

축하고 ethyl acetate $2 \mathrm{~mL}$ 로 재용해하여 기기 분석하였다. 분해 시간을 확립하기 위해 $200{ }^{\circ} \mathrm{C}$ 에서 20 분, 40 분, 60 분의 가열시 간을 검토하였다. Prochloraz 뿐 아니라 대사물의 2,4,6-TCP 분 해율을 확인하기 위해 prochloraz를 이용해 확립된 분해조건 하 에서 BTS44595 및 BTS44596 표준용액 $1 \mu \mathrm{g} / \mathrm{mL}, 1 \mathrm{~mL}$ 를 이 용해 분해 및 회수율을 확인하였다.

\section{Aminopropyl SPE 정제조건 설정}

2,4,6-TCP 분해 및 분배액에 잔존하는 분석 방해물질 제거를 위 해 $\mathrm{NH}_{2} \mathrm{SPE}$ (solid phase extraction) cartridge을 활용한 추가 정제 조건을 검토하였으며, 고기류에 한해 조건을 확립하였다. $\mathrm{NH}_{2}$ SPE cartridge $(1 \mathrm{~g}, 6 \mathrm{cc})$ 를 dichloromethane $10 \mathrm{~mL}$ 로 활 성화시킨 후 $2,4,6-\mathrm{TCP}$ 표준용액 $1 \mu \mathrm{g} / \mathrm{mL}, 1 \mathrm{~mL}$ 를 질소 건고 한 다음 dichloromethane $5 \mathrm{~mL}$ 로 재용해한 용액을 카트리지에 첨가하였다. 최적의 용출조건을 확립하기 위해 methanol/ dichloromethane 혼합액, acetone, methanol, $n$-hexane 및 $1 \%$ formic acid를 함유한 methanol으로 용출시켜 회수율을 확인하 였다.

\section{분석정량한계 및 회수율 확인}

Prochloraz 분석을 위한 각 세부 전처리법을 확정한 후 ILOQ, 시료채취량, 시험용액 부피, 분석조작에 따른 희석 또는 농축배 수를 고려하여 전체 분석법의 분석정량한계(Method limit of quantitation, MLOQ)를 산출하였다[10]. 확정된 전처리 방법 및 기기분석법에 따른 prochloraz 잔류분석의 정확성과 정밀성을 확인하기 위해 회수율 실험을 실시하였다. 표준용액 첨가법에 따라 처리수준이 MLOQ 및 MLOQ의 10배가 되도록 prochloraz 표준용액을 소고기, 돼지고기, 닭고기, 우유 및 계란 $10 \mathrm{~g}$ 에 첨
가하였다. 고기류의 경우 acetone $100 \mathrm{~mL}$ 를 첨가 후 $200 \mathrm{rpm}$ 에 서 30 분간 진탕 추출한 후 filter paper가 깔려있는 뷰흐너 깔때 기로 감압여과한 다음 잔사를 acetone $50 \mathrm{~mL}$ 로 세척하였다. 추 출액에 $2 \%$ diethylene glycol $0.2 \mathrm{~mL}$ 을 첨가하고 감압 농축한 후 acetonitrile에 포화된 $n$-hexane $50 \mathrm{~mL}$ 로 재 용해하여 $n$ hexane에 포화시킨 $1 \%$ formic acid 함유된 acetonitrile $50 \mathrm{~mL}$ 를 이용해 2 번 분배 후 $40{ }^{\circ} \mathrm{C}$ 수욕상에서 감압 농축하였다. 우 유 및 계란의 경우 추출용매 acetone $20 \mathrm{~mL}$ 첨가 후 $200 \mathrm{rpm}$ 에서 30 분간 진탕 추출하고, $3500 \mathrm{rpm}$ 에서 5 분간 원심분리한 후 상등액을 분액여두로 옮겨 증류수 $250 \mathrm{~mL}$ 와 포화식염수 50 $\mathrm{mL}$ 를 넣고 dichloromethane $50 \mathrm{~mL}$ 로 두 번 분배하였다. 분배 액을 sodium sulfate, anhydrous을 통과시켜 탈수한 후 $40{ }^{\circ} \mathrm{C}$ 수욕상에서 감압 농축하였다. 감압농축 후 잔사 고형물을 dichloromethane $10 \mathrm{~mL}$ 로 재용해한 후 그 중 $1 \mathrm{~mL}$ 를 분해용 vial에 옮기고 $2 \%$ diethylene glycol $0.2 \mathrm{~mL}$ 첨가한 후 질소 농축하였다. 분해용 vial에 pyridine hydrochloride $5 \mathrm{~g}$ 을 첨가하 고 $220{ }^{\circ} \mathrm{C}$ 에서 1 시간 분해 후 상온에서 방치한 다음 $0.2 \mathrm{M}$ $\mathrm{HCl}$ 수용액 $20 \mathrm{~mL}$ 재 용해하고 분액여두로 옮겼다. 증류수 100 $\mathrm{mL}$ 와 포화식염수 $50 \mathrm{~mL}$ 를 첨가하고 dichloromethane $50 \mathrm{~mL}$ 으 로 2 번 분배한 후 sodium sulfate, anhydrous을 통과시켜 탈수 하고 $2 \%$ diethylene glycol $0.2 \mathrm{~mL}$ 를 첨가한 다음 $40{ }^{\circ} \mathrm{C}$ 수욕 상에서 감압 농축하고 ethyl acetate $2 \mathrm{~mL}$ 로 잔사 고형분을 재 용해하여 기기 분석하였다. 닭고기의 경우 추가정제가 필요하여 위의 잔사를 dichloromethane $5 \mathrm{~mL}$ 에 재용해하여 dichloromethane $10 \mathrm{~mL}$ 로 활성화시킨 $\mathrm{NH}_{2}$ cartridge $(1 \mathrm{~g}, 6 \mathrm{cc}$ )에 loading하였다. Methanol $10 \mathrm{~mL}$ 를 흘려 세척하여 버린 후 $1 \%$ formic acid를 함유한 methanol을 $10 \mathrm{~mL}$ 용출하여 받아 질소 농축하여 ethyl acetate $2 \mathrm{~mL}$ 로 재용해하여 기기 분석하였다. 이 과정을 3 번 반 
복 실험하여 축산물별 처리수준별 회수율을 산출하였다.

\section{결과 및 고찰}

\section{GC-ECD 분석법 확립 및 검중}

Prochloraz 및 대사물들은 모두 2,4,6-trichlorophenol moiety를 함유하고 있어 분자구조 내 chlorine 원자 3개를 함유하고 있으 므로 검출기로는 $\mathrm{ECD}$ 를 이용하였다[3]. 2,4,6-TCP 분석이 가능 한 기기분석 조건을 탐색하기 위해 분리능이 우수한 capillary column으로 보편적으로 많이 DB-5 column을 선정하고 온도조 절 등 기기분석 조건을 최적화하였다. Prochloraz 및 대사물의 개별분석이 가능한지 각각 분석해 보았으나, prochloraz가 $\mathrm{GC}$ 분석 중 열분해가 발생되어 prochloraz peak와 함께 2,4,6-TCP peak가 동시에 확인이 되어 $\mathrm{GC}$ 를 이용한 개별분석은 불가하였 다. $2,4,6-\mathrm{TCP}$ 의 ILOQ $(\mathrm{S} / \mathrm{N} \geq 10)$ 는 $0.005 \mu \mathrm{g} / \mathrm{mL}$ 으로 결정되었 다. 해당 분석조건에서 $2,4,6-\mathrm{TCP}$ 의 머무름 시간 7.9 분이었으며 기기상의 정량한계 농도인 $0.005 \mu \mathrm{g} / \mathrm{mL}$ 를 7 번 반복 분석한 결 과는 변이계수(C.V.)는 $10 \%$ 이내를 만족하였고, 표준 검량선의 결정계수 $\left(\mathrm{R}^{2}\right)$ 는 모두 0.995 이상으로 우수한 직선성을 보였다(Fig. 2).

\section{축산물 중 추출용매 선정}

축산물 고기류 중 돼지고기를 이용하여 최적의 추출조건을 검 토하였으며, 추출용매로써 acetone과 acetonitrile을 이용하여 진 탕추출한 결과 acetone에 비해 acetonitrile은 고기 시료가 응집 되는 현상이 관찰되었다. 계란 및 우유의 경우 acetone 사용 시 시료내의 단백질 응집 등에 큰 효과를 보여 원심분리를 통해 매질분리 효과가 뛰어났기 때문에 추출용매로 acetone을 선정하 였다.

\section{축산물 추출물의 분배법 확립}

고기류에는 다량의 유지와 비극성 간섭물질을 함유하고 있어 정 밀한 농약잔류분석을 방해한다. 고기류 중 지질을 제거하기 위 해 $n$-hexane/acetonitrile 분배를 검토하였으며, 이는 추출 후의 과정이므로 prochloraz와 대사물별로 확인하였다. 분배 시 formic acid 첨가 유무에 관계없이 분배 회수율은 약 $90 \%$ 이상 의 만족스러운 수준이었지만, 대사물 BTS44596이 산성 조건에 서 안정하므로 $1 \%$ formic acid가 함유된 $n$-hexane/acetonitrile 분배법으로 확립하였다(Table 1). 돼지고기 $10 \mathrm{~g}$ 의 acetone 추출 량은 $7.18 \mathrm{~g}$ 이었고 확립된 $n$-hexane/acetonitrile 분배법을 통한 추출액의 지질 제거율은 $98.4 \%$ 로 높은 지질 제거효과를 보였 다. 계란 및 우유 중 prochloraz 및 대사물의 액-액 분배법을 검토한 결과, 검토한 모든 분배법에서 모든 성분들이 $85 \%$ 이 상의 우수한 분배 회수율을 보였다(Table 2). 따라서, 전처리 시 간을 최소화할 수 있도록 추출액에 과량의 물을 첨가한 후 dichloromethane으로 분배하는 과정으로 최종 확립하였다.

\section{Prochloraz 및 대사물의 2,4,6-TCP로 분해}

Prochloraz는 $200{ }^{\circ} \mathrm{C}$ 에서 열분해성이 있어 $\mathrm{GLC}$ 분석시 안정하 지 못하여 pyridine hydrochloride를 첨가하여 고온에서 열분해 시켜 2,4,6-TCP로 전환하여 분석하는 방법을 검토하였다[3].
Table $1 n$-hexane/acetonitrile partition of prochloraz and its metabolites

\begin{tabular}{ccc}
\hline \hline \multirow{2}{*}{ Compounds } & \multicolumn{2}{c}{ Efficiency $(\%)^{1)}$} \\
\cline { 2 - 3 } & Partition I $^{2)}$ & Partition II $^{3)}$ \\
\hline Prochloraz & 97.7 & 100.6 \\
2,4,6-trichlorophenol & 98.3 & 89.9 \\
BTS44595 & 96.8 & 100.1 \\
BTS44596 & 99.5 & 97.2 \\
\hline
\end{tabular}

${ }^{1)}$ mean, $\mathrm{n}=2$

2) $1 \mathrm{~mL}$ of standard solution $10 \mu \mathrm{g} / \mathrm{mL}, 30 \mathrm{~mL}$ of $n$-hexane, $30 \mathrm{~mL}$ of acetonitrile $(\times 2)$

3) $1 \mathrm{~mL}$ of standard solution $10 \mu \mathrm{g} / \mathrm{mL}, 30 \mathrm{~mL}$ of $1 \%$ formic acid in $n$ hexane, $30 \mathrm{~mL}$ of $1 \%$ formic acid in acetonitrile $(\times 2)$

Table 2 Liquid-liquid partition of prochloraz and its metabolites

\begin{tabular}{|c|c|c|c|}
\hline \multirow{2}{*}{ Compounds } & \multicolumn{3}{|c|}{ Efficiency $(\%)^{1)}$} \\
\hline & Partition $\mathrm{I}^{2)}$ & Partition $\mathrm{II}^{3)}$ & Partition $\left.\mathrm{III}^{4}\right)$ \\
\hline Prochloraz & 95.9 & 97.9 & 87.9 \\
\hline 2,4,6-trichlorophenol & 85.3 & 93.6 & 98.6 \\
\hline BTS44595 & 93.2 & 96.3 & 92.1 \\
\hline BTS44596 & 97.9 & 102.1 & 97.1 \\
\hline
\end{tabular}

1) mean, $\mathrm{n}=2$

2) $1 \mathrm{~mL}$ of standard solution $10 \mu \mathrm{g} / \mathrm{mL}, 150 \mathrm{~mL}$ of acetone, $50 \mathrm{~mL}$ of sat. $\mathrm{NaCl}, 450 \mathrm{~mL}$ of distilled water, $50 \mathrm{~mL}$ of dichloromethane $(\times 2)$

${ }^{3} 1 \mathrm{~mL}$ of standard solution $10 \mu \mathrm{g} / \mathrm{mL}, 150 \mathrm{~mL}$ of acetonitrile, $50 \mathrm{~mL}$ of sat. $\mathrm{NaCl}, 450 \mathrm{~mL}$ of distilled water, $50 \mathrm{~mL}$ of dichloromethane $(\times 2)$

4) $1 \mathrm{~mL}$ of standard solution $10 \mu \mathrm{g} / \mathrm{mL}, 50 \mathrm{~mL}$ of sat. $\mathrm{NaCl}, 200 \mathrm{~mL}$ of distilled water, $50 \mathrm{~mL}$ of dichloromethane $(\times 2)$

Pyridine hydrochloride는 상온에서 고체이며 녹는점이 $144{ }^{\circ} \mathrm{C}$ 이기에 분해온도 조건에서는 액체 형태로 변하였다. 분해물에서 2,4,6-TCP를 분배 회수하기 위해 앞서 계란 및 우유에서 확립 한 dichloromethane를 이용한 액-액 분배법을 적용검토하였다. $2,4,6-\mathrm{TCP}$ 을 비해리성으로 변환시키기 위해 2,4,6-TCP $0.1 \mu \mathrm{g}$ 이 포함된 분해액을 $0.2 \mathrm{M} \mathrm{HCl}$ 수용액으로 녹였으며 dichloromethane 으로 분배회수한 결과 $113 \%$ 의 우수한 회수율을 보였다. Prochloraz는 열분해 온도 $200{ }^{\circ} \mathrm{C}$ 이상, 분해시간 40 분 이상 진 행하였을 때 대부분이 2,4,6-TCP로 전환이 일어났으며, 분해율 의 재현성을 높이기 위해 $220{ }^{\circ} \mathrm{C}, 1$ 시간 동안 분해하는 것으로 열분해 조건을 확립하였다(Table 3). 확립된 분해조건에서 prochloraz, 대사물 BTS44595 및 BTS44596 각각 $1 \mu \mathrm{g}(1 \mu \mathrm{g} /$ $\mathrm{mL}, 1 \mathrm{~mL}$ )의 열분해율은 각각 $122.9,122.5$ 및 $119.8 \%$ 으로 완 전한 분해를 확인하였으며, $100 \%$ 이상의 높은 $2,4,6-\mathrm{TCP}$ 로의 분해율은 각 표준용액이 제조되어질 때의 농도 오차, one-point calibration 정량 등으로 인한 것이었을 뿐 분해율을 확인하는데 문제는 없었다.

\section{Aminopropyl SPE 정제 최적화}

닭고기를 제외한 고기류, 계란 및 우유는 2,4,6-TCP 분해 및 액 -액 분배 후 기기분석을 통해 $2,4,6-\mathrm{TCP}$ 를 정량하는데 문제가 없었으나, 닭고기 control 시료의 크로마토그램상의 baseline이 매우 불안정하고 간섭물질이 다량 확인되어 추가 정제방법을 검 토하였고 2,4,6-TCP가 약해리성이기에 $\mathrm{NH}_{2} \mathrm{SPE}$ 를 이용하였다. 최적의 용출조건을 확립하기 위해 methanol/dichloromethane의 
Table 3 Decomposition of prochloraz according to heating temperature and times

\begin{tabular}{cccc}
\hline \hline $\begin{array}{c}\text { Temperature } \\
\left({ }^{\circ} \mathrm{C}\right)\end{array}$ & $\begin{array}{c}\text { Decomp. Rate } \\
(\%)^{1)}\end{array}$ & Time (min) & $\begin{array}{c}\text { Decomp. Rate } \\
(\%)^{2)}\end{array}$ \\
\hline 200 & 118.5 & 20 & 34.3 \\
210 & 117.1 & 40 & 93.5 \\
220 & 122.9 & 60 & 121.5 \\
\hline
\end{tabular}

1) $1 \mathrm{~mL}$ of prochloraz $1 \mu \mathrm{g} / \mathrm{mL}, 5 \mathrm{~g}$ of pyridine hydrochloride, $1 \mathrm{hr}$ of decomposition time

${ }^{2)} 1 \mathrm{~mL}$ of prochloraz $1 \mu \mathrm{g} / \mathrm{mL}, 5 \mathrm{~g}$ of pyridine hydrochloride, $200{ }^{\circ} \mathrm{C}$ of decomposition temperature

Table 4 Purification of 2,4,6-trichlorophenol using aminopropyl SPE cartridge $(1 \mathrm{~g})$

\begin{tabular}{cccc}
\hline $\begin{array}{c}\text { Composition of } \\
\text { Eluate }^{1)}\end{array}$ & $\begin{array}{c}\text { Recovery } \\
(\%)^{3)}\end{array}$ & Eluate & $\begin{array}{c}\text { Recovery } \\
(\%)^{3)}\end{array}$ \\
\hline $5: 95$ & 0 & Acetone & 0 \\
$10: 90$ & 0 & Methanol & 0 \\
$20: 80$ & 0 & $n$-hexane & 0 \\
$30: 70$ & 0 & $1 \%$ formic acid in methanol & 115.7 \\
\hline
\end{tabular}

1) $10 \mathrm{~mL}$ of mixture of methanol/dichloromethane

2) $10 \mathrm{~mL}$ of solvent

3) mean, $\mathrm{n}=2$

Table 5 Recoveries and MLOQ of prochloraz in animal commodities

\begin{tabular}{ccccc}
\hline \hline Commodities & $\begin{array}{c}\text { Fortification } \\
(\mathrm{mg} / \mathrm{kg})\end{array}$ & $\begin{array}{c}\text { Recovery } \\
(\%)^{1)}\end{array}$ & $\begin{array}{c}\text { C.V. } \\
(\%)^{2)}\end{array}$ & $\begin{array}{c}\text { MLOQ } \\
(\mathrm{mg} / \mathrm{kg})\end{array}$ \\
\hline Beef meat & 0.02 & $90.4 \pm 6.9$ & 7.6 & 0.02 \\
\hline \multirow{2}{*}{ Pork meat } & 0.2 & $99.6 \pm 5.4$ & 5.4 & 0.02 \\
\hline \multirow{2}{*}{ Chicken meat } & 0.02 & $98.9 \pm 5.9$ & 6.0 & \multirow{2}{*}{0.02} \\
\hline \multirow{2}{*}{ Milk } & 0.2 & $94.4 \pm 2.1$ & 2.2 & 0.02 \\
\hline \multirow{2}{*}{ Egg } & 0.02 & $107.1 \pm 2.8$ & 2.6 & 0.02 \\
\hline
\end{tabular}

1) mean $\pm \mathrm{SD}, \mathrm{n}=3$

${ }^{2)}$ coefficient variation

비율을 조절하며 용출시켜 보았지만 2,4,6-TCP이 전혀 용출되 지 않았고 acetone, methanol 및 $n$-hexane으로도 용출되지 않았 으나, $1 \%$ formic acid를 함유한 methanol로 용출하였을 때 전 량이 용출되었다(Table 4). 따라서, methanol $10 \mathrm{~mL}$ 로 세척 후 $1 \%$ formic acid가 함유된 methanol $10 \mathrm{~mL}$ 로 용출하는 것으로 $\mathrm{SPE}$ 정제조건을 확립하였다.

\section{분석정량한계(MLOQ), 분석법 정확성 및 정밀성 검증}

앞서 각 분석과정별 조건이 확립되었으며 $2,4,6-\mathrm{TCP}$ 의 ILOQ $0.005 \mu \mathrm{g} / \mathrm{mL}$, 기기주입량 $1 \mu \mathrm{L}$, 시험용액 $2 \mathrm{~mL}$, 분배액 중 $1 \mathrm{~mL}$ 분해, 시료채취량 $10 \mathrm{~g}$ 을 고려하여 2,4,6-TCP의 MLOQ 는 $0.01 \mathrm{mg} / \mathrm{kg}$ 로 산출되었고 prochloraz로써 환산할 경우 prochloraz의 MLOQ는 $0.02 \mathrm{mg} / \mathrm{kg}$ 이었다. 축산물 중 prochloraz
의 잔류허용기준은 최소 $0.05 \mathrm{mg} / \mathrm{kg}$ 이므로 확립된 분석법의 정 량한계는 기준적부 판정을 위한 잔류분석법으로써 그 기준을 만 족하였다[11-12]. 본 연구에서 확립된 전처리 방법에 따라 조제 된 축산물별 시험용액을 $\mathrm{GC} / \mathrm{ECD}$ 로 분석하였을 때, $2,4,6-\mathrm{TCP}$ 의 머무름 시간대에 불순물의 간섭이 관찰되지 않음으로써 분 석의 선택성은 양호하였다(Supplemental 1). 확립된 전처리 방 법 및 기기분석법에 따른 분석의 정확성과 정밀성을 확인하기 위해 MLOQ $(0.02 \mu \mathrm{g} / \mathrm{kg})$ 및 $10 \mathrm{MLOQ}(0.2 \mu \mathrm{g} / \mathrm{kg})$ 수준의 회 수율 시험을 수행하였다. 회수율은 두 가지 처리수준에 걸쳐 각 각 소고기 84.0-105.6\%, 돼지고기 90.4-114.8\%, 닭고기 94.1$112.0 \%$, 우유 $99.8-118.7 \%$ 및 계란 $101.4-110.2 \%$ 의 범위를 보 였고 변이계수는 $9.0 \%$ 이하이었으며(Table 5), 잔류분석기준인 회수율 $70-120 \%$, 변이계수 $10 \%$ 이내를 만족하였다[12]. 따라서, 본 연구에서 확립된 분석법은 축산물 중 prochloraz 및 대사체 를 정량분석하는데 정확성 및 정밀도가 우수함을 확인하였으며, 축산물 중 잔류농약 실태조사 및 정량평가 등에 활용될 수 있 을 것으로 기대된다.

\section{초 록}

축산물 중 살균제 prochloraz 및 그의 대사체의 잔류량을 함께 정량분석할 수 있는 단성분 분석법을 개발하고자 하였다. 축산 물 중 prochloraz의 잔류분의 정의가 'prochloraz와 2,4,6trichlorophenol기를 포함하고 있는 대사산물의 합을 prochloraz 로 함'이기 때문에 prochloraz 및 대사산물을 모두 2,4,6trichlorophenol $(2,4,6-\mathrm{TCP})$ 로 분해시킨 후 $\mathrm{GC} / \mathrm{ECD}$ 로 정량하는 정밀 분석법을 확립하였다. 대표 축산물인 소고기, 돼지고기, 닭 고기, 우유 및 계란 중 prochloraz 잔류분을 acetone으로 추출 하고 2,4,6-TCP로 분해한 후 dichloromethane으로 분배하고 aminopropyl SPE로 정제한 다음 $2,4,6-\mathrm{TCP}$ 를 정량하였다. 본 분석법을 통한 기기정량한계와 분석법정량한계는 prochloraz의 경우 각각 $0.01 \mu \mathrm{g} / \mathrm{mL}$ 과 $0.02 \mathrm{mg} / \mathrm{kg}$ 이었으며 $2,4,6-\mathrm{TCP}$ 는 $0.005 \mu \mathrm{g} / \mathrm{mL}$ 과 $0.01 \mathrm{mg} / \mathrm{kg}$ 이었다. 2,4,6-TCP를 이용한 표준검량 선은 $0.005-0.2 \mathrm{mg} / \mathrm{L}$ 범위에서 결정계수 $\left(\mathrm{R}^{2}\right) \geq 0.995$ 으로 직선성 을 확인하였다. 분석법의 회수율은 분석정량한계 및 정량한계의 10 배 처리수준에서 실시하여 모두 $90 \%$ 이상이었고 변이계수는 $10 \%$ 이하이었다. 따라서, 본 연구에서 확립된 분석법은 축산물 중 prochloraz 및 대사체를 정량분석하는데 우수한 정확성 및 정밀도를 보였으며, 축산물 중 prochloraz 잔류분석을 위한 정 밀시험법으로써 분석개발기준을 충족하였다.

Keywords 잔류분석법 · 축산물 · Prochloraz · 2,4,6-trichlorophenol

감사의 글 본 연구는 2017년도 식품의약품안전처의 연구개발비(16162MFDS586) 로 수행되었으며 이에 감사드립니다.

\section{References}

1. MAFRA (2017) Primary statistics of agriculture, food and rural affairs. Ministry of Agriculture, Food and Rural Affairs, Sejong, Korea, pp 382383 
2. KCPA (2020) Guideline crop protection agents. Korea Crop Protection Association, Seoul, Korea

3. Turner JA (2018) The pesticide manual, 18th edn. British Crop Protection Council, Hampshire, UK, pp 922-923

4. FAO (2004) Pesticide residues in food 2004. In: Report of Joint Meeting of the FAO Panel of Experts on Pesticide Residues in Food and the Environment and the WHO Core Assessment Group on Pesticide Residues, FAO Plant Production and Protection Paper 178. Food and Agriculture Organization of the United Nations, Rome, Italy, pp 163-180

5. Fang Q, Yao G, Shi Y, Ding C, Wang Y, Wu X, Hua R, Cao H (2017) Residue dynamics and risk assessment of prochloraz and its metabolite 2,4,6-trichlorophenol in apple. Molecules 22: 1780

6. Fuse JI, Kanamori H, Ideyoshi N (2000) Determination of prochloraz and its metabolites in fruits and vegetables by GC. Food Hyg Safety Sci 41: $61-65$

7. Lee EM, Lee HR, Riu MJ, Park HW, Na YR, Song HH, Keum YS, Zhu Y, Kim JH (2009) Establishment of analytical method of prochloraz in cabbage, apple, mandarin, pepper and hulled rice with GC-ECD. Korean J Environ Agric 28: 427-434

8. MFDS (2020) Prochloraz. In: Food code, Ministry of Food and Drug Safety, Cheongju, Korea, pp 924-925

9. Fu Y, Wang Q, Zhang L, Wu Y (2020) Simultaneous determination of prochloraz and three metabolites in fruits and vegetables by liquid chromatography-tandem mass spectrometry (LC-MS/MS). Analytical Letters 53: 355-370

10. Lee H, Choi H, Kim BJ, Kim E, Kim SH, Lee JB, Lee YD, Kim JH (2017) Establishment of analytical method for pencycuron in representative agricultural commodities by high-performance liquid chromatography. Korean J Pestic Sci 21: 75-83

11. MFDS (2020) Attached table 6, Pesticides MRLs in livestock \& aquatic products. In: Food Code, Ministry of Food and Drug Safety, Cheongju, Korea, pp 10

12. MFDS (2016) Guidelines on standard procedures for preparing analysis method. Ministry of Food and Drug Safety, Cheongju, Korea 